\title{
Dynamic evolution of European airport systems in the context of Low- Cost Carriers growth
}

\author{
Jimenez, Edgar(a,b)*; Claro, João(a); Pinho de Sousa, Jorge(a); de Neufville, Richard(c) \\ (a) INESC TEC and Faculdade de Engenharia da Universidade do Porto; Rua Dr. Roberto Frias s/n, 4200 \\ - 465, Porto, Portugal \\ (b) Universidad de Ibagué - GMAE Group, Civil Engineering Department; Carrera 22 Calle 67, 730002, \\ Ibague, Colombia
}

(c) Massachusetts Institute of Technology - Engineering Systems Division; 77 Massachusetts Ave. 021394307, Cambridge, MA, USA.

* Corresponding author: edgar.jimenez@unibague.edu.co

\begin{abstract}
Airport systems adapted to the influx of Low-Cost Carriers (LCC) as the segment grew to prominence in the European market during the last decades. The generalised perspective that LCCs are attached to remote secondary airports is being increasingly challenged by recent moves of the largest European LCC. The reality is that the impact of LCCs has spread to most commercial airports in Europe, primary and secondary alike. Yet, despite valuable insights on the evolution of airline networks, existing literatures lacks a clear understanding of why this has occurred. This paper explains the dynamics in the evolution of airports systems that resulted in significant growth for the low-cost segment in Europe. A multiple case study involving 42 European airports provides evidence to identify the mechanisms that trigger the traffic patterns leading to the ascendency of LCCs in their respective airport systems. Understanding these mechanisms may probe valuable for airport strategic planning.
\end{abstract}

\section{Highlights}

- LCCs in Europe have significantly impacted both major and secondary airports

- New infrastructure encourages the growth of LCCs, even if not directly aimed at LCCs

- Market dynamics led many European airports to focus on LCC traffic 


\section{Introduction}

Liberalisation of the air transport market around the world has profoundly changed the evolution trends of the aviation industry. A liberalised market created a proper environment for Low-Cost Carriers (LCC) to emerge and favoured their rapid expansion. Yet after decades of liberalisation the academic literature is not conclusive on the long-term impact of this trend for airports (A. Graham, 2013). There is concern about the growing market power of LCCs and its implications for airports, and there is uncertainty about the future evolution of the business models, not only for LCCs but for traditional airlines too (European Parliament, 2007).

An important body of literature links the emergence of LCCs to the availability of 'secondary' airports where they could thrive avoiding direct competition with other airlines (Barbot, 2006; de Neufville, 2008; Dobruszkes, 2006, 2013; Francis, Fidato, \& Humphreys, 2003; Francis, Humphreys, \& Ison, 2004; Franke, 2004; Zhang, Hanaoka, Inamura, \& Ishikura, 2008). This aspect has been studied as a trigger for competition between airports (Jimenez, Claro, \& Pinho de Sousa, 2013; Pels, Njegovan, \& Behrens, 2009) a factor for airport efficiency (Martini, Manello, \& Scotti, 2013), and as a potential asset to increase network connectivity (Malighetti, Paleari, \& Redondi, 2008). Yet recent developments in Europe show that primary airports are in the core of LCC expansion and that the implication of this trend for smaller secondary airports remain unclear (Dobruszkes, Givoni, \& Vowles, 2017).

In order to understand such implications, it is necessary to understand first how LCCs start, expand or abandon service at a given airport and how other airlines and airports react. And that needs to be assessed over time to gain a clearer picture of foreseeable trends. To the best of our knowledge, existing literature (covered in the next section) describes extensively what has happened to the low-cost segment over time, but still lacks a clear understanding on how the current landscape formed. Gaining insights on such details may be valuable for airport planners and policy makers to discern possible outcomes of the current trends.

In that sense, this papers proposes a dynamic perspective to study the evolution of European airport systems regarding LCC influence. Given that 16 of the top 20 European airports with the largest amount of seats provided by LCCs in 2013 belonged to a Multi-Airport System (MAS), we examined the evolution at 42 airports (all the airports in each MAS plus the four single-airport systems) between 2004 and 2013.. Over this period LCCs became major players at both primary and secondary airports in Europe, contrary to the generalised notion that LCCs are attached to remote secondary airports.

We considered two types of dynamics in the evolution of the airport systems: infrastructure-related and market-related dynamics. The interaction of different dynamics result in particular traffic patterns with commonalities that are recognisable among diverse airport systems. By understanding such dynamics, airport managers may improve their planning processes considering both infrastructure development and strategy formulation simultaneously. 
The paper is structured in six sections. After this introduction, the second section reviews relevant literature and defines the gaps that this research addresses. Section 3 describes the methodology used for the research. Section 4 summarises the most relevant findings from the traffic evolution at the airports selected for the study. Section 5 introduces the mechanisms that produce generic traffic patterns extracted from the multiple case studies. And section 6 presents the main findings and implications for policy making.

\section{The impact of LCCs on airport systems}

Airports are systems in the sense that they do not operate independently (de Neufville \& Odoni, 2003); they are part of networks in which decisions made in one airport can affect others. This is more evident when different airports serve the same region, i.e., when they are part of Multi-Airport Systems (MAS). In an MAS airports compete with each other for traffic and services (Copenhagen Economics, 2012; de Neufville \& Odoni, 2003; Jimenez et al., 2013; Pels et al., 2009) generating complex dynamics for planning and operations (de Neufville, 1995a, 1995b). Bonnefoy (2008) studied some of those dynamics to determine how airport systems can be scaled by developing into an MAS along time.

Over the last decades LCCs have disrupted airport systems, particularly in North America and Europe (de Neufville, 2008). The impact that LCCs have on airports have been ample matter of research, yet "the academic literature is far less clear and conclusive about the overall impacts of LCC operations at airports and the extent to which airports benefit from LCCs, particularly in the long-term, and this suggests that more studies are needed" (A. Graham, 2013). Indeed, many studies have focused on specific airports within a limited time frame, or on the airlines (Barret, 2004; European Parliament, 2007; Francis et al., 2003, 2004; Gillen \& Lall, 2004; B. Graham \& Shaw, 2008; Malighetti, Paleari, \& Redondi, 2009; Malighetti, Redondi, Martini, \& Paleari, 2007; Martini et al., 2013).

Consequently, it is commonly agreed that LCCs prefer 'secondary' airports (Barbot, 2006; de Neufville, 2008; Dobruszkes, 2006, 2013; Zhang et al., 2008). However Abda et al. (2012) found that, in the USA, the market shares of LCCs were bigger at the largest primary airports, "contrary to the common perception that LCCs avoid primary airports and direct competition with the [Full Service Carriers]" (A. Graham, 2013). This indicates that LCCs are becoming increasingly dominant in some markets (in particular the intra-USA and intra-European markets) and, as they keep growing, they move to the primary airports. In fact, the recent evolution of the networks of LCCs in Europe (Dobruszkes, 2006, 2009, 2013; Dobruszkes et al., 2017) suggests similar developments as the business models of the airlines evolve.

The expansion of LCCs at larger primary airports poses interesting questions for practitioners and researchers. How do these airports respond if their infrastructure has been normally developed for the use of traditional airlines? What factors favour or hinder LCC growth at primary and secondary airports? Are LCCs abandoning secondary airports altogether? What are the implications of these issues for policy 
making?

In order to contribute towards filling such gaps, this paper proposes a dynamic perspective to study how LCCs have affected the evolution of European airport systems. The main factors that guided particular paths of evolution in the airport systems may suggest insights for the future development as LCCs keep growing and legacy airlines compete more strongly. Understanding the dynamics of such evolution is paramount to cope with the inherent volatility and uncertainty in airport systems, increased by trends associated to LCCs.

\section{Methodology}

In order to study the evolution of airport systems with special consideration for the low-cost segment, we selected the 20 European airports with the largest offer of low-cost seats in 2013, as per Innovata data (IATA, n.d.). As most of them (16) belong to Multi-Airport Systems (MAS), we also included all the other airports in every relevant MAS to analyse their evolution and mutual influences. Hence, we performed a multiple-case study comprising an extensive document review coupled with an analysis of traffic trends for each of the 42 resulting airports (see Table) during the period between 2004 and 2013. The analysis of traffic trends is primarily based on airline capacity (available seats) data, from the Innovata database (IATA, n.d.) aggregated for the years 2004, 2008, 2012 and 2013. In the case of Spanish airports we have also used data provided by AENA Aeropuertos, the airport operator, in terms of passengers per airline for every year between 2005 to 2013 (AENA, 2014). In the case of British airports, we complemented capacity information with passenger traffic data, aggregated at the airport level (i.e. not by carrier) between 1998 and 2013 (CAA, 2014).

The document review included public documents in different languages, mainly the periodic reports of airport operators and civil aviation authorities, as well as their websites, aviation industry news and analyses, and mainstream and local journals. Traffic trends were assessed using nonhierarchical cluster analysis to group airports according to the relevance of low-cost traffic at the start (2004) and end (2013) of the analysis period. A non-hierarchical approach using k-means clustering (Forgy, 1965; Lloyd, 1982) based on euclidean quadratic distances was selected due to the relatively small sample (the 42 airports were grouped in their respective 17 airport systems) and the insights gained from the case studies that preliminarily hinted the possible number of clusters. Results of the cluster analysis were evaluated using Dunn (Dunn, 1974; Rousseeuw, 1987) and silhouette indexes. To select the appropriate number of clusters Dunn and silhouette indexes should be high. 
Table 1: Airports selected for detailed dynamic analysis by MAS (the 20 airports with the largest amount of LCC seats in 2013 are highlighted bold).

\begin{tabular}{|c|c|c|c|c|c|c|c|}
\hline $\begin{array}{l}\text { IATA } \\
\text { Code }\end{array}$ & Airport & MAS & $\begin{array}{l}\text { Rank by LCC } \\
\text { seats (2013) }\end{array}$ & $\begin{array}{l}\text { IATA } \\
\text { Code }\end{array}$ & Airport & MAS & $\begin{array}{l}\text { Rank by LCC } \\
\text { seats (2013) }\end{array}$ \\
\hline ALC & Alicante (Elche) & Alicante & 16 & SEN & Southend & London & 116 \\
\hline MJV & Murcia San Javier & Alicante & 111 & STN & Stansted & London & 3 \\
\hline AMS & Schiphol & Amsterdam & 11 & LBA & Leeds Bradford & Manchester & 49 \\
\hline EIN & Eindhoven & Amsterdam & 42 & LPL & Liverpool & Manchester & 30 \\
\hline RTM & Rotterdam & Amsterdam & 108 & MAN & Manchester (Ringway) & Manchester & 6 \\
\hline BCN & El Prat & Barcelona & 1 & BGY & Bergamo & Milan & 8 \\
\hline GRO & Gerona & Barcelona & 48 & LIN & Linate & Milan & 134 \\
\hline REU & Reus & Barcelona & 139 & MXP & Malpensa & Milan & 12 \\
\hline BRU & Brussels Zaventem & Brussels & 85 & OSL & Oslo (Gardermoen) & Oslo & 5 \\
\hline CRL & Charleroi & Brussels & 20 & RYG & Rygge & Oslo & 62 \\
\hline $\mathrm{CPH}$ & Copenhagen (Kastrup) & Copenhagen & 17 & TRF & Torp (Sandefjord) & Oslo & 92 \\
\hline MMX & Malmo & Copenhagen & 120 & BVA & Beauvais & Paris & 33 \\
\hline EDI & Edinburgh & Glasgow & 18 & CDG & Charles de Gaulle & Paris & 26 \\
\hline GLA & Glasgow Intl & Glasgow & 36 & ORY & Orly & Paris & 15 \\
\hline PIK & Prestwick & Glasgow & 101 & XCR & Vatry & Paris & 292 \\
\hline IST & Ataturk & Istanbul & 158 & $\mathrm{CIA}$ & Ciampino & Rome & 27 \\
\hline SAW & Sabiha Gokcen & Istanbul & 4 & FCO & Fiumicino & Rome & 19 \\
\hline LCY & London City & London & - & AGP & Malaga (Costa del Sol) & - & 10 \\
\hline LGW & Gatwick & London & 2 & DUB & Dublin & - & 9 \\
\hline LHR & Heathrow & London & 135 & MAD & Madrid Barajas & - & 14 \\
\hline LTN & Luton & London & 7 & PMI & Palma de Mallorca & - & 13 \\
\hline
\end{tabular}

In the document review we collected information regarding two types of dynamics in the evolution of every airport: infrastructure-related and market-related dynamics. Infrastructure-related dynamics mostly focus on capacity expansion in the passenger buildings and the air-side facilities (runway system and aprons); as well as in the redevelopment of existing airports or construction of new greenfield airports. Market-related dynamics refer to external events affecting the aviation industry in a global or local context (such as the 2008 economic recession, or the opening of the Madrid - Barcelona HighSpeed Rail line for airports in or near Madrid and Barcelona); management strategies (Malighetti et al., 2007) from the airports or airlines that affect their competitive position or their operations (such as mergers or acquisitions, change of strategic focus, creation of spin-off or start-up companies, opening or closing of bases or hubs); and vicissitudes that affect airline or airport operations (such as bankruptcies and legal disputes).

The 42 airports were studied by MAS in order to allow for an analysis of the impacts that events in one airport may have on the other airports of the MAS. Given the extent of the exercise, Annex A summarises the most relevant findings of the multiple-case study according to the type of dynamics examined for every airport system. Likewise, the next section highlights the outcomes of the analysis of traffic 
evolution at the airports under study. Traffic evolution, besides the analysis shown in the next section, was examined on a carrier-by-carrier basis for each airport system over the period of analysis. Such details, however, are too extensive to be reproduced in this paper. Interested readers are referred to (Jimenez, 2015) for more information.

\section{Traffic evolution at European airport systems}

Table 2 shows traffic evolution at the 42 airports by MAS and type of airline (Non-LCC and LCC) between 2004 and 2013. Cell colours show the trends in growing or declining traffic for every segment in each MAS: Dark green backgrounds signal a large number of Non-LCC traffic (relative to the MAS) whilst dark orange signals a large number of LCC seats (also relative to the MAS). In every airport system low-cost traffic grew considerably from the levels of 2004. Yet in most cases of Multi-Airport Systems, low-cost traffic grew more significantly at the primary airports, to the point that the primary ${ }^{1}$ airports had the largest share of LCC traffic in every MAS by 2013 as Table illustrates. Moreover, the prominent growth of LCCs made Brussels Charleroi (CRL) and Milan Bergamo (BGY) airports transition from secondary to primary airports in their respective MAS according to the definition set by Bonnefoy (2008).

Some airports had a clear change in focus as low-cost traffic filled the void of fewer legacy traffic, whether as an intended strategy where LCCs were actively promoted by airport management, as in the case of London Gatwick (LGW); or unintended as a result of the interaction of the different dynamics summarised in Annex A and described in more detail in the next section, as in the cases of Barcelona El Prat (BCN), Malaga (AGP), Alicante (ALC), Milan Malpensa (MXP), Edinburgh (EDI), and to a lesser extent Madrid (MAD), Palma de Mayorca (PMI), Rome Fiumicino (FCO), Copenhagen (CPH) and Paris Orly (ORY).

In Multi-Airport Systems the smaller airports usually provide less room for expansion, hence it was more common that low-cost traffic moved from secondary to primary airports in the MAS. This happened especially when there was capacity available at the primary airport even when such capacity was not intentionally built for LCCs. Table and Table show this evolution clearly for the MAS in Alicante and Barcelona. There were also cases in which primary airports provided sufficient capacity for LCCs to capture demand growth that was more difficult for FSCs to stimulate, as in Amsterdam (AMS), Paris Charles de Gaulle (CDG), Oslo (OSL) and Glasgow (GLA).

Secondary airports have played an important role in fostering the growth of LCCs, particularly in the initial phases that made the low-cost business model viable at large scale. Although in most cases secondary airports cannot provide the same levels of capacity than primary airports, some secondary airports were able to secure prime positions for low-cost traffic within their MAS. As pointed out above Milan Bergamo (BGY) and Brussels Charleroi (CRL) stand out in this regard, along with Paris Beauvais

1 Bonnefoy (2008) considers primary airports those that handle over 20\% of total traffic in a Multi-Airport System (secondary airports thus handle $20 \%$ or less). In the case of systems with a single airport that is naturally considered a primary one. 
Table 2: Traffic evolution (available seats) by type of airline in the sampled airports. Source: Innovata.

\begin{tabular}{|c|c|c|c|c|c|c|c|c|c|c|}
\hline \multirow{3}{*}{$\begin{array}{l}\text { IATA } \\
\text { Code }\end{array}$} & \multirow{3}{*}{ MAS } & \multicolumn{8}{|c|}{ Available seats (thousands) } & \multirow{3}{*}{$\begin{array}{c}\text { Airport } \\
\text { type }\end{array}$} \\
\hline & & \multicolumn{4}{|c|}{ Non-LCC } & \multicolumn{4}{|c|}{ LCC } & \\
\hline & & 2004 & 2008 & 2012 & 2013 & 2004 & 2008 & 2012 & 2013 & \\
\hline ALC & \multirow{2}{*}{ Alicante } & 2.167 & 2.525 & 1.316 & 1.391 & 1.525 & 3.241 & 3.701 & 4.265 & $P$ \\
\hline MJV & & 92 & 146 & 76 & 59 & 403 & 1.012 & 606 & 618 & $\mathrm{~S}$ \\
\hline AMS & \multirow{3}{*}{ Amsterdam } & 24.183 & 25.505 & 25.080 & 25.583 & 1.707 & 3.586 & 4.772 & 4.935 & $P$ \\
\hline EIN & & 174 & 41 & 25 & 6 & 161 & 844 & 1.777 & 2.029 & $\mathrm{~S}$ \\
\hline RTM & & 664 & 200 & 123 & 304 & 0 & 475 & 573 & 666 & $S$ \\
\hline $\mathrm{BCN}$ & \multirow{3}{*}{ Barcelona } & 15.830 & 13.599 & 9.424 & 8.113 & 1.703 & 8.051 & 13.745 & 13.815 & $P$ \\
\hline GRO & & 66 & 116 & 40 & 33 & 1.501 & 3.337 & 1.813 & 1.807 & $S$ \\
\hline REU & & 20 & 197 & 159 & 134 & 242 & 428 & 375 & 445 & $S$ \\
\hline BRU & \multirow{2}{*}{ Brussels } & 9.087 & 11.816 & 11.126 & 11.199 & 1.302 & 1.072 & 1.073 & 1.041 & $P$ \\
\hline CRL & & 25 & 24 & 328 & 396 & 1.258 & 1.750 & 3.765 & 3.832 & $P$ \\
\hline $\mathrm{CPH}$ & \multirow{2}{*}{ Copenhagen } & 13.370 & 14.253 & 11.929 & 11.904 & 922 & 701 & 3.183 & 3.961 & $P$ \\
\hline MMX & & 731 & 813 & 696 & 769 & 161 & 129 & 537 & 561 & $S$ \\
\hline EDI & \multirow{3}{*}{ Glasgow } & 3.108 & 2.655 & 2.228 & 2.434 & 2.106 & 3.351 & 3.686 & 3.890 & $P$ \\
\hline GLA & & 2.975 & 2.704 & 2.250 & 2.318 & 1.370 & 2.412 & 2.207 & 2.325 & $P$ \\
\hline PIK & & 11 & 12 & 0 & 0 & 1.110 & 1.654 & 703 & 756 & $S$ \\
\hline IST & \multirow{2}{*}{ Istanbul } & 9.394 & 16.543 & 29.235 & 32.353 & 35 & 111 & 321 & 342 & $P$ \\
\hline SAW & & 0 & 1.059 & 1.805 & 3.288 & 43 & 1.336 & 6.232 & 7.938 & $P$ \\
\hline LCY & \multirow{6}{*}{ London } & 1.619 & 3.320 & 2.508 & 2.673 & 119 & 0 & 0 & 0 & $S$ \\
\hline LGW & & 10.245 & 12.509 & 9.005 & 8.726 & 3.366 & 7.662 & 11.151 & 11.944 & $P$ \\
\hline LHR & & 46.024 & 46.634 & 45.570 & 46.847 & 106 & 146 & 421 & 473 & $P$ \\
\hline LTN & & 170 & 351 & 308 & 323 & 4.042 & 5.944 & 5.492 & 5.470 & $S$ \\
\hline SEN & & 1 & 0 & 64 & 48 & 0 & 3 & 371 & 582 & $S$ \\
\hline STN & & 1.029 & 1.408 & 428 & 360 & 11.239 & 12.913 & 10.266 & 10.528 & $\mathrm{~S}$ \\
\hline LBA & \multirow{3}{*}{ Manchester } & 582 & 535 & 303 & 361 & 761 & 1.420 & 1.626 & 1.802 & $S$ \\
\hline $\mathrm{LPL}$ & & 209 & 28 & 17 & 0 & 1.623 & 3.436 & 2.904 & 2.749 & $S$ \\
\hline MAN & & 7.388 & 8.512 & 7.126 & 7.160 & 1.389 & 3.609 & 5.013 & 5.635 & $P$ \\
\hline BGY & \multirow{3}{*}{ Milan } & 362 & 362 & 142 & 139 & 1.519 & 3.752 & 5.237 & 5.238 & $P$ \\
\hline LIN & & 5.184 & 6.376 & 6.112 & 5.817 & 579 & 277 & 617 & 479 & $P$ \\
\hline MXP & & 11.679 & 9.793 & 6.449 & 6.262 & 333 & 2.850 & 5.288 & 4.882 & $P$ \\
\hline OSL & \multirow{3}{*}{ Oslo } & 9.054 & 10.041 & 9.277 & 9.645 & 1.830 & 3.791 & 5.748 & 6.319 & $P$ \\
\hline RYG & & 0 & 13 & 45 & 35 & 0 & 292 & 1.243 & 1.384 & $\mathrm{~S}$ \\
\hline TRF & & 458 & 388 & 451 & 476 & 299 & 700 & 788 & 916 & $S$ \\
\hline BVA & \multirow{4}{*}{ Paris } & 7 & 66 & 8 & 51 & 853 & 1.637 & 2.455 & 2.476 & $\mathrm{~S}$ \\
\hline CDG & & 34.609 & 36.888 & 35.113 & 34.784 & 1.228 & 3.024 & 3.007 & 2.928 & $P$ \\
\hline ORY & & 14.938 & 14.633 & 13.634 & 13.841 & 1.527 & 3.094 & 3.982 & 4.267 & $P$ \\
\hline $\mathrm{XCR}$ & & 0 & 0 & 11 & 10 & 0 & 0 & 49 & 56 & $\mathrm{~S}$ \\
\hline $\mathrm{ClA}$ & \multirow{2}{*}{ Rome } & 146 & 23 & 0 & 0 & 1.482 & 2.926 & 2.868 & 2.926 & $S$ \\
\hline FCO & & 18.756 & 23.086 & 20.089 & 19.242 & 972 & 1.839 & 4.138 & 3.841 & $P$ \\
\hline AGP & Malaga* & 3.970 & 4.123 & 2.451 & 2.445 & 1.925 & 3.568 & 4.723 & 4.973 & $P$ \\
\hline DUB & Dublin* & 6.434 & 8.204 & 7.381 & 7.809 & 3.576 & 6.954 & 4.965 & 5.083 & $P$ \\
\hline MAD & Madrid* & 27.009 & 30.209 & 24.166 & 21.335 & 527 & 4.251 & 6.364 & 4.550 & $P$ \\
\hline PMI & Palma* & 6.569 & 10.236 & 7.723 & 7.588 & 1.107 & 2.297 & 4.588 & 4.824 & $P$ \\
\hline
\end{tabular}

Notes: * Single-airport system. Dark green indicates large number of Non-LCC seats in relation to the MAS. Dark orange indicates large number of LCC seats in relation to the MAS. Airport type according to Bonnefoy (2008) based on 2013 traffic: P = Primary (>

(BVA) and Rome Ciampino (CIA) to a lesser extent. Ciampino, however, is in fact a former primary airport that was able to attract low-cost traffic when all airlines moved to the then new primary airport in the MAS (Fiumicino - FCO). 
Table 3. Evolution of LCC market shares in each airport and MAS. Source: Innovata.

\begin{tabular}{|c|c|c|c|c|c|c|c|c|c|c|}
\hline \multirow{3}{*}{$\begin{array}{l}\text { IATA } \\
\text { Code }\end{array}$} & \multirow{3}{*}{ MAS } & \multicolumn{8}{|c|}{ Proport in of Available seats } & \multirow{3}{*}{$\begin{array}{c}\text { Airport } \\
\text { type }\end{array}$} \\
\hline & & \multicolumn{4}{|c|}{ Share of LCC traf $\mathbf{E}$ in the airport } & \multicolumn{4}{|c|}{ Share of LCC traf $\mathbf{E}$ in the MAS } & \\
\hline & & 2004 & 2008 & 2012 & 2013 & 2004 & 2008 & 2012 & 2013 & \\
\hline ALC & \multirow{2}{*}{ Alicante } & $41,3 \%$ & $56,2 \%$ & $73,8 \%$ & $75,4 \%$ & $79,1 \%$ & $76,2 \%$ & $85,9 \%$ & $87,3 \%$ & $P$ \\
\hline MJV & & $81,4 \%$ & $87,4 \%$ & $88,9 \%$ & $91,3 \%$ & $20,9 \%$ & $23,8 \%$ & $14,1 \%$ & $12,7 \%$ & $S$ \\
\hline AMS & \multirow{3}{*}{ Amsterdam } & $6,6 \%$ & $12,3 \%$ & $16,0 \%$ & $16,2 \%$ & $91,4 \%$ & $73,1 \%$ & $67,0 \%$ & $64,7 \%$ & $P$ \\
\hline EIN & & $48,1 \%$ & $95,4 \%$ & $98,6 \%$ & $99,7 \%$ & $8,6 \%$ & $17,2 \%$ & $25,0 \%$ & $26,6 \%$ & $\mathrm{~S}$ \\
\hline RTM & & $0,0 \%$ & $70,4 \%$ & $82,3 \%$ & $68,7 \%$ & $0,0 \%$ & $9,7 \%$ & $8,0 \%$ & $8,7 \%$ & $\mathrm{~S}$ \\
\hline $\mathrm{BCN}$ & \multirow{3}{*}{ Barcelona } & $9,7 \%$ & $37,2 \%$ & $59,3 \%$ & $63,0 \%$ & $49,4 \%$ & $68,1 \%$ & $86,3 \%$ & $86,0 \%$ & $P$ \\
\hline GRO & & $95,8 \%$ & $96,6 \%$ & $97,8 \%$ & $98,2 \%$ & $43,6 \%$ & $28,2 \%$ & $11,4 \%$ & $11,2 \%$ & $S$ \\
\hline REU & & $92,4 \%$ & $68,5 \%$ & $70,2 \%$ & $76,9 \%$ & $7,0 \%$ & $3,6 \%$ & $2,4 \%$ & $2,8 \%$ & $\mathrm{~S}$ \\
\hline BRU & \multirow{2}{*}{ Brussels } & $12,5 \%$ & $8,3 \%$ & $8,8 \%$ & $8,5 \%$ & $50,9 \%$ & $38,0 \%$ & $22,2 \%$ & $21,4 \%$ & $P$ \\
\hline CRL & & $98,1 \%$ & $98,6 \%$ & $92,0 \%$ & $90,6 \%$ & $49,1 \%$ & $62,0 \%$ & $77,8 \%$ & $78,6 \%$ & $\mathrm{P}$ \\
\hline $\mathrm{CPH}$ & \multirow{2}{*}{ Copenhagen } & $6,5 \%$ & $4,7 \%$ & $21,1 \%$ & $25,0 \%$ & $85,1 \%$ & $84,5 \%$ & $85,6 \%$ & $87,6 \%$ & $P$ \\
\hline MMX & & $18,0 \%$ & $13,7 \%$ & $43,6 \%$ & $42,2 \%$ & $14,9 \%$ & $15,5 \%$ & $14,4 \%$ & $12,4 \%$ & $\mathrm{~S}$ \\
\hline EDI & \multirow{3}{*}{ Glasgow } & $40,4 \%$ & $55,8 \%$ & $62,3 \%$ & $61,5 \%$ & $45,9 \%$ & $45,2 \%$ & $55,9 \%$ & $55,8 \%$ & $P$ \\
\hline GLA & & $31,5 \%$ & $47,1 \%$ & $49,5 \%$ & $50,1 \%$ & $29,9 \%$ & $32,5 \%$ & $33,5 \%$ & $33,4 \%$ & $P$ \\
\hline PIK & & $99,0 \%$ & $99,3 \%$ & $100,0 \%$ & $100,0 \%$ & $24,2 \%$ & $22,3 \%$ & $10,7 \%$ & $10,8 \%$ & $\mathrm{~S}$ \\
\hline IST & \multirow{2}{*}{ Istanbul } & $0,4 \%$ & $0,7 \%$ & $1,1 \%$ & $1,0 \%$ & $44,9 \%$ & $7,7 \%$ & $4,9 \%$ & $4,1 \%$ & $P$ \\
\hline SAW & & $100,0 \%$ & $55,8 \%$ & $77,5 \%$ & $70,7 \%$ & $55,1 \%$ & $92,3 \%$ & $95,1 \%$ & $95,9 \%$ & $\mathrm{P}$ \\
\hline LCY & \multirow{6}{*}{ London } & $6,8 \%$ & $0,0 \%$ & $0,0 \%$ & $0,0 \%$ & $0,6 \%$ & $0,0 \%$ & $0,0 \%$ & $0,0 \%$ & $\mathrm{~S}$ \\
\hline LGW & & $24,7 \%$ & $38,0 \%$ & $55,3 \%$ & $57,8 \%$ & $17,8 \%$ & $28,7 \%$ & $40,3 \%$ & $41,2 \%$ & $P$ \\
\hline LHR & & $0,2 \%$ & $0,3 \%$ & $0,9 \%$ & $1,0 \%$ & $0,6 \%$ & $0,5 \%$ & $1,5 \%$ & $1,6 \%$ & $P$ \\
\hline LTN & & $96,0 \%$ & $94,4 \%$ & $94,7 \%$ & $94,4 \%$ & $21,4 \%$ & $22,3 \%$ & $19,8 \%$ & $18,9 \%$ & $S$ \\
\hline SEN & & $0,0 \%$ & $100,0 \%$ & $85,3 \%$ & $92,4 \%$ & $0,0 \%$ & $0,0 \%$ & $1,3 \%$ & $2,0 \%$ & $S$ \\
\hline STN & & $91,6 \%$ & $90,2 \%$ & $96,0 \%$ & $96,7 \%$ & $59,6 \%$ & $48,4 \%$ & $37,1 \%$ & $36,3 \%$ & $S$ \\
\hline LBA & \multirow{3}{*}{ Manchester } & $56,7 \%$ & $72,6 \%$ & $84,3 \%$ & $83,3 \%$ & $20,2 \%$ & $16,8 \%$ & $17,0 \%$ & $17,7 \%$ & $S$ \\
\hline LPL & & $88,6 \%$ & $99,2 \%$ & $99,4 \%$ & $100,0 \%$ & $43,0 \%$ & $40,6 \%$ & $30,4 \%$ & $27,0 \%$ & $S$ \\
\hline MAN & & $15,8 \%$ & $29,8 \%$ & $41,3 \%$ & $44,0 \%$ & $36,8 \%$ & $42,6 \%$ & $52,5 \%$ & $55,3 \%$ & $P$ \\
\hline BGY & \multirow{3}{*}{ Milan } & $80,8 \%$ & $91,2 \%$ & $97,4 \%$ & $97,4 \%$ & $62,5 \%$ & $54,5 \%$ & $47,0 \%$ & $49,4 \%$ & $P$ \\
\hline LIN & & $10,0 \%$ & $4,2 \%$ & $9,2 \%$ & $7,6 \%$ & $23,8 \%$ & $4,0 \%$ & $5,5 \%$ & $4,5 \%$ & $P$ \\
\hline MXP & & $2,8 \%$ & $22,5 \%$ & $45,1 \%$ & $43,8 \%$ & $13,7 \%$ & $41,4 \%$ & $47,5 \%$ & $46,1 \%$ & $P$ \\
\hline OSL & \multirow{3}{*}{ Oslo } & $16,8 \%$ & $27,4 \%$ & $38,3 \%$ & $39,6 \%$ & $86,0 \%$ & $79,3 \%$ & $73,9 \%$ & $73,3 \%$ & $P$ \\
\hline RYG & & - & $95,7 \%$ & $96,5 \%$ & $97,5 \%$ & - & $6,1 \%$ & $16,0 \%$ & $16,1 \%$ & $\mathrm{~S}$ \\
\hline TRF & & $39,5 \%$ & $64,3 \%$ & $63,6 \%$ & $65,8 \%$ & $14,0 \%$ & $14,6 \%$ & $10,1 \%$ & $10,6 \%$ & $S$ \\
\hline BVA & \multirow{4}{*}{ Paris } & $99,2 \%$ & $96,1 \%$ & $99,7 \%$ & $98,0 \%$ & $23,6 \%$ & $21,1 \%$ & $25,9 \%$ & $25,5 \%$ & $\mathrm{~S}$ \\
\hline CDG & & $3,4 \%$ & $7,6 \%$ & $7,9 \%$ & $7,8 \%$ & $34,0 \%$ & $39,0 \%$ & $31,7 \%$ & $30,1 \%$ & $\mathrm{P}$ \\
\hline ORY & & $9,3 \%$ & $17,5 \%$ & $22,6 \%$ & $23,6 \%$ & $42,3 \%$ & $39,9 \%$ & $41,9 \%$ & $43,9 \%$ & $P$ \\
\hline XCR & & - & - & $81,7 \%$ & $84,8 \%$ & $0,0 \%$ & $0,0 \%$ & $0,5 \%$ & $0,6 \%$ & $S$ \\
\hline $\mathrm{ClA}$ & \multirow{2}{*}{ Rome } & $91,0 \%$ & $99,2 \%$ & $100,0 \%$ & $100,0 \%$ & $60,4 \%$ & $61,4 \%$ & $40,9 \%$ & $43,2 \%$ & $S$ \\
\hline $\mathrm{FCO}$ & & $4,9 \%$ & $7,4 \%$ & $17,1 \%$ & $16,6 \%$ & $39,6 \%$ & $38,6 \%$ & $59,1 \%$ & $56,8 \%$ & $P$ \\
\hline AGP & Malaga* & $32,7 \%$ & $46,4 \%$ & $65,8 \%$ & $67,0 \%$ & $100,0 \%$ & $100,0 \%$ & $100,0 \%$ & $100,0 \%$ & $P$ \\
\hline DUB & Dublin* & $35,7 \%$ & $45,9 \%$ & $40,2 \%$ & $39,4 \%$ & $100,0 \%$ & $100,0 \%$ & $100,0 \%$ & $100,0 \%$ & $P$ \\
\hline MAD & Madrid* & $1,9 \%$ & $12,3 \%$ & $20,8 \%$ & $17,6 \%$ & $100,0 \%$ & $100,0 \%$ & $100,0 \%$ & $100,0 \%$ & $P$ \\
\hline PMI & Palma* & $14,4 \%$ & $18,3 \%$ & $37,3 \%$ & $38,9 \%$ & $100,0 \%$ & $100,0 \%$ & $100,0 \%$ & $100,0 \%$ & $P$ \\
\hline
\end{tabular}

Interestingly, other airports that are usually considered as secondary within their MAS were actually intended to replace or extend capacity for legacy traffic in the cities they serve (London Stansted - STN - and Istanbul Sabiha Gokcen - SAW, for instance). As the expected traffic did not materialise, LCCs were better fit to use these facilities. 
These developments were contrasted with the results of the cluster analysis. In order to be able to replicate the data available ( Table) and focus on the relative position of LCCs in each airport, we produced seven input variables. Three of them were the same but on two different periods (2004 and 2013): the market share of primary airports in the MAS, the market share of LCCs at primary airports in the MAS, and the market share of LCCs at secondary airports in the MAS. The other variable was the traffic (available seats) growth rate in each MAS between 2004 and 2013.

Given that traffic growth at Istanbul MAS was extraordinary during the period of analysis (364\%), compared to the rest of MAS, different combinations were tested for the cluster analysis. Several clusters were produced considering all airports and not considering the growth variable, whilst varying the number of clusters; and again considering all variables and considering Istanbul as an outlier. The significance of the results was first contrasted against the findings in the multiple-case study for all the airports and it was more satisfactory when Istanbul MAS was included. Then validity indexes to select the appropriate number of clusters where calculated for every alternative. As Table shows, four clusters deliver the best performance for Dunn and silhouette indexes.

Table 4. Values of Dunn and Silhouette indexes to select number of clusters.

\begin{tabular}{lll}
\hline Number of clusters & Dunn index & Silhouette index \\
\hline 3 & 0,686 & 0,605 \\
\hline $\mathbf{1}$ & $\mathbf{1 , 6 6 9}$ & $\mathbf{0 , 7 3 8}$ \\
\hline 5 & 1,289 & 0,408 \\
\hline
\end{tabular}

Table shows the airport systems included in each of the clusters selected. Based on the findings of the multiple-case study summarised in Annex A, Table also presents a qualitative description of each cluster, as well as the mechanisms of low-cost traffic evolution that were deduced from the mixed quantitative/qualitative approach. The mechanisms are further detailed in the next section.

Table 5: Clusters of airport systems according to low-cost traffic evolution.

\begin{tabular}{|c|c|c|c|}
\hline Cluster & MAS & Description & Mechanisms \\
\hline 1 & Alicante & \multirow{4}{*}{$\begin{array}{l}\text { MAS where primary airport(s) reacted to LCC growth in } \\
\text { secondary airport(s) and developed a stronger position in } \\
\text { the MAS due to fostering low-cost growth mainly through } \\
\text { infrastructure expansion that was not intended for LCCs }\end{array}$} & $\mathrm{I} 1, \mathrm{M} 1$ \\
\hline 1 & Barcelona & & II,M1 \\
\hline 1 & Glasgow & & I1,M1 \\
\hline 1 & Manchester & & $\mathrm{M} 1, \mathrm{I} 1$ \\
\hline 2 & Brussels & \multirow{6}{*}{$\begin{array}{l}\text { MAS where where secondary airport(s) gained and } \\
\text { sustained a strong position in the MAS due to fostering } \\
\text { low-cost growth. Primary airport(s) reacted by allowing } \\
\text { LCCs and secondary airport(s) remained strong in the } \\
\text { MAS }\end{array}$} & 13 \\
\hline 2 & Istanbul & & 12 \\
\hline 2 & London & & I3,M1 \\
\hline 2 & Milan & & I3,M1 \\
\hline 2 & Paris & & 13 \\
\hline 2 & Rome & & $12, \mathrm{M} 1$ \\
\hline 3 & Amsterdam & \multirow{3}{*}{$\begin{array}{l}\text { MAS where primary airport allowed (but not } \\
\text { straightforward fostered) LCC growth focused on more } \\
\text { hybrid LCCs. Secondary airport(s) captured ultra-LCCs }\end{array}$} & 12 \\
\hline 3 & Copenhagen & & $12, \mathrm{M} 1$ \\
\hline 3 & Oslo & & $12, \mathrm{M} 1$ \\
\hline 4 & Malaga & \multirow{4}{*}{$\begin{array}{l}\text { Single-Airport Systems subject to strong market dynamics } \\
\text { that jeopardised the position of the major FSC users and } \\
\text { LCCs replaced legacy carriers and captured growth using } \\
\text { infrastructure expansion not intended for LCCs }\end{array}$} & I1,M1 \\
\hline 4 & Dublin & & I1,M1 \\
\hline 4 & Madrid & & I1,M1 \\
\hline 4 & Palma & & $\mathrm{M} 1, \mathrm{I} 1$ \\
\hline \multicolumn{4}{|c|}{$\begin{array}{l}\text { Mechanisms: } \\
\text { I1-Capacity expansion at primary air } \\
\text { I2- New/emerged primary airport } \\
\text { I3- New/emerged secondary airport } \\
\text { M1 - Market dynamics }\end{array}$} \\
\hline
\end{tabular}




\section{Mechanisms of low-cost traffic evolution at European airports}

Despite the particular characteristics that make every case unique, we used the 42 case studies to identify four generic mechanisms that trigger distinctive patterns of traffic evolution. Three of them relate to infrastructure dynamics: i) Capacity expansion at primary airports, ii) new/emerged primary airports, and iii) new/emerged secondary airports ${ }^{2}$. The fourth mechanism is directly related to the market dynamics occurring in the airport system. The mechanisms normally occurred in a combination of infrastructure plus market dynamics to produce a given outcome or traffic pattern.

\subsection{Capacity expansion at primary airports (I1)}

The first mechanism relates to the implementation of a major capacity expansion at a primary (or at the only) airport in the system. In this case low-cost traffic is typically promoted because the airport is unable to attract the foreseen growth in non-LCC traffic that had justified the expansion (see Fig. 1). Given that additional capacity is deployed in discrete amounts, some airports invest in large expansions, based on long-term forecasts that are highly uncertain.

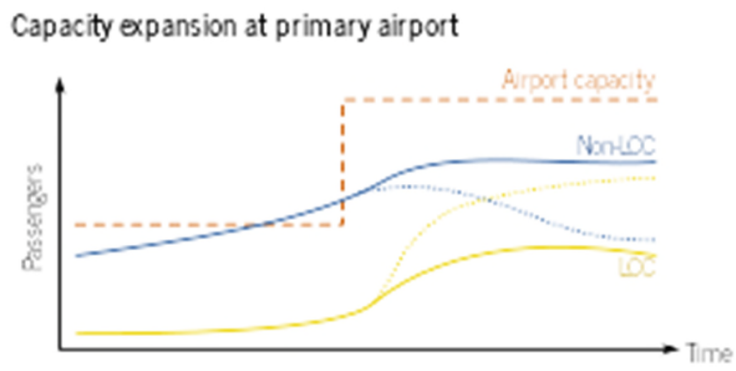

Fig. 1. Typical traffic patterns at a primary airport before and after considerable capacity expansion.

When investments are realised (typically 2 to 6 years after construction started depending on the scale of the project, and 5 to 15 years after planning - i.e. forecasting - started) external conditions that affect demand are different (as in the case of Spanish airports in which most major expansions opened amid economic recession). If expected demand does not occur, unused facilities with high fixed costs become a burden for the airport operator. LCCs (and in particular the largest European LCCs) have large fleets that can be deployed quickly and flexibly to stimulate demand with low fares and occupy the new space. This pattern is more visible when capacity was added by building new separate passenger buildings. The old ones either close or attract LCCs.

If demand for traditional airlines effectively grow but not at the expected rate, the marginal cost of providing capacity for LCCs is much lower than before the expansion, when the airport was more congested. In this case LCCs can also thrive at the airport by exploring new markets with higher yields.

2 New secondary airports may become primary (as per Bonnefoy, 2008) if they concentrate enough traffic growth, as in the case of Brussels Charleroi (CRL) and Miilan Bergamo (BGY). 


\subsection{New/emerged primary airports (I2)}

The second mechanism involves the emergence of a new primary airport in the region, not necessarily a greenfield project as major redevelopment of former facilities can also be considered. When, in a given airport system, a new primary airport is built (or an existing airport is extensively redeveloped to become a primary airport), there are typically two patterns of evolution according to whether the new/emerged airport is able to capture traffic or not (see Fig. 2).

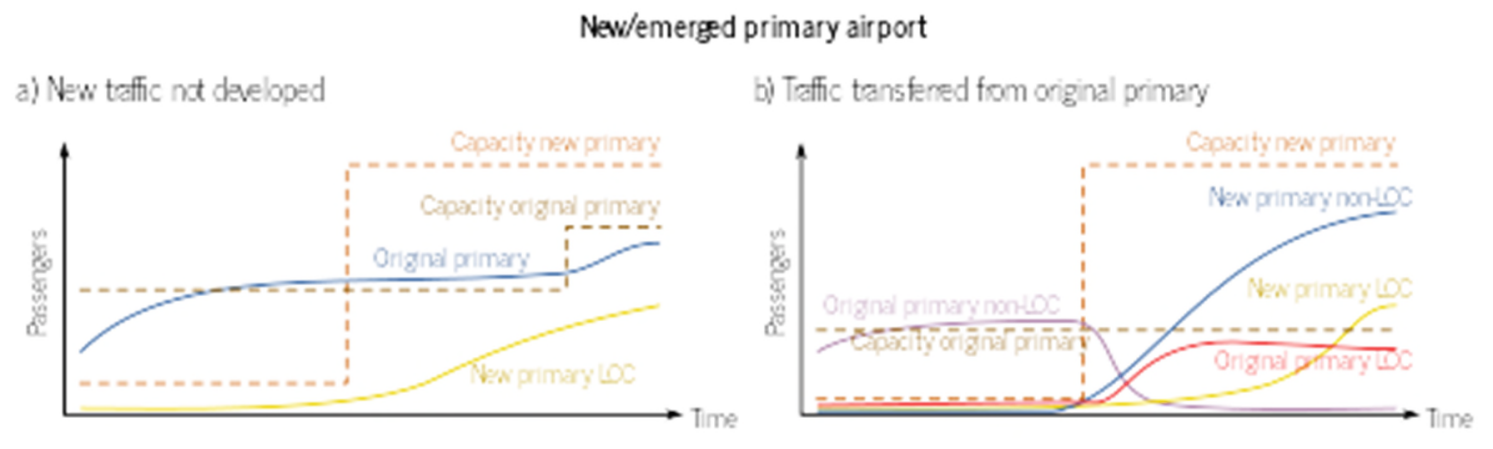

Fig. 2. Typical traffic patterns when a new or redeveloped primary airport emerge.

In the first case (Fig. 2 left) the new airport opens, the old one is not closed, and its traffic is not forced to transfer to the new location. As traffic does not materialise in the new facilities, the airport operator needs to increase revenues to balance high fixed costs and LCCs become a natural option for the airport to foster growth. In the meantime, capacity at the original primary airport may be increased to cope with congestion. Eventually, some LCCs may operate from the original primary airport as well, especially through acquisitions or mergers, whilst some non-LCC carriers may also use the new/emerged airport, especially foreign FSCs or charters.

London Stansted (STN) and Istanbul Sabiha Gokcen (SAW) are the best examples of this pattern. Built to alleviate congestion in other primary airports, STN and SAW only grew to prominence when LCCs started regular services.

In the second case (Fig. 2 right) traffic is transferred from the original primary airport to the new development, but the old airport is not dismantled. Eventually, low-cost traffic may develop almost exclusively in the original primary airport (which can become a secondary one if traffic at the new primary grows considerably) but limited to the available capacity. When capacity is reached, the airport is not expanded (usually there is no space to do it, this being the reason for the new development) and some LCCs can go to the new/emerged primary airport to continue growing. The Rome MAS illustrates this case very well. Fiumicino (FCO) was built to replace Ciampino (CIA) as the main airport, after some years empty CIA turned a secondary airport for LCCs but then most LCCs started expanding at FCO when capacity limits were reached at CIA.

It may also happen that the original primary airport gets closed and dismantled (as in Oslo or as it is planned for Berlin). The new airport can be designed with different types of traffic in mind and thus allow space for the growth of LCCs. Or, especially when the new location becomes inconvenient for some 
travellers (as in the case of Oslo), the new primary airport can foster the (re)development of secondary airports that mainly target LCCs.

Sometimes the new primary airport does not capture any traffic at all. Montreal Mirabel Airport is perhaps the most renowned case. Examples in Europe are not uncommon though: the 1.1 billion Euro Ciudad Real Airport (intended to be South Madrid Airport) opened in December 2008 and closed in 2012 with less than 100000 passengers over that period; the Region de Murcia International Airport, also in Spain, has not seen its first passenger despite construction ended in 2012; opening of Berlin Brandenburg has been severely delayed and it is not expected to happen soon.

\subsection{New/emerged secondary airports (I3)}

The third mechanism relates to the emergence of a new, or existing but underused, secondary airport in the region served by an existing primary airport. In this case the emerging airport typically attracts mostly low-cost traffic (see Fig. 3). In many cases, secondary airports accompanied the initial expansion of LCCs and their developers provided incentives or better opportunities to capture that market (as in Charleroi, Luton, Liverpool, Bergamo, Beauvais, for instance). For start-up LCCs, these airports offered a lower cost but also lacked congestion and had simple layouts that favoured streamlined efficient operations.

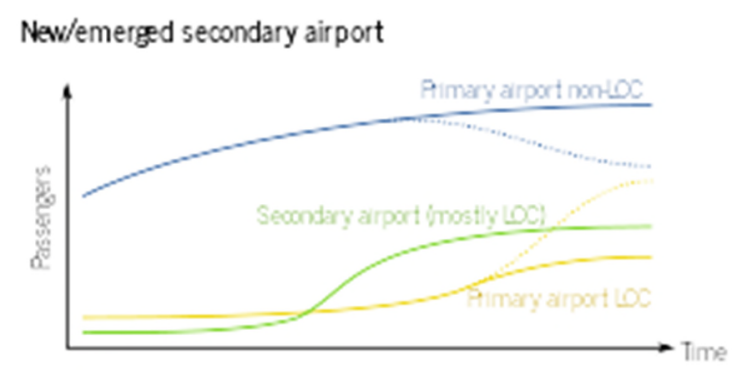

Fig. 3. Typical traffic patterns when a new or redeveloped secondary airport emerge.

Emerged secondary airports can also foster the growth of LCCs at the primary airport mainly by raising awareness of competition between airlines and between airports. Thus, as Fig. shows, low-cost traffic at the primary airport may become more important than at the secondary airport, particularly when LCCs with a more hybrid proposition come to the primary airport. In addition, if non-LCC carriers cannot sustain competition from their low-cost counterpart, the significance of LCC traffic at the primary airport can also increase as these airlines downsize their operations.

Secondary airports may also fail to attract traffic, thus facing closure or downscaling, transferring part of their LCC traffic to primary airports (or to other secondary airports). Paris Vatry (XCR), for instance, has not been able to establish significant operations since its redevelopment. Forli Airport, in Italy, went bankrupt in 2013 and most flights moved to Rimini and Bologna nearby. Hamburg Lubeck, filed for bankruptcy in early 2014 and ended commercial services by 2016. Beja Airport, located in between Lisbon and the Algarve in Portugal, opened in 2011 aiming at attracting LCCs but has not attracted any regular scheduled operator to date. 


\subsection{Market dynamics (M1)}

The fourth mechanism involves the occurrence of market dynamics at a given primary or secondary airport affecting either the airlines that use the airports or the airports themselves. Market dynamics imply changes in the traffic mix of the airport system that are not directly related to changes in the infrastructure. These include new LCC start-ups, changes in the commercial focus of a major airline (from FSC or charter to LCC, or vice versa, for instance) at the airport, or of the airport itself (due to change in ownership or management); bankruptcy or downscaling of a major airline (de-hubbing, for instance); and mergers or acquisitions.

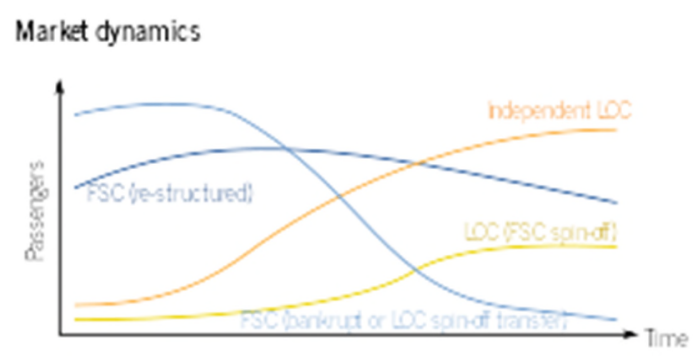

Fig. 4. Typical traffic patterns after market disruptions.

Fig. 4 shows the typical traffic pattern that leads to strengthened position of LCCs at an airport following market-related dynamics. The overall growth of LCCs in Europe increased competition with traditional 'legacy' and charter carriers, and this in turn added pressure for these airlines to control their costs and, in many cases, to restructure and concentrate their operations. For many small regional airports this meant that LCCs were the only viable alternative to sustain traffic. Other major airports changed their attitude towards LCCs as the airlines they were used to serve gradually (or suddenly in some cases) vanished or transformed themselves.

As Fig. 4 illustrates, typically LCCs are keen to substitute the void left by 'legacy' carriers that went bankrupt. Moreover, 'legacy' carriers may replace themselves with their in-house LCC subsidiaries to focus on their hubs for long-haul traffic. The major independent LCCs (Ryanair, easyJet, Norwegian, Vueling before IAG acquisition, or Wizz Air, for instance) usually gain larger market shares because they have larger fleets and better financial positions to fund expansion.

\subsection{Stages of dynamic airport evolution in relation to low-cost traffic}

The different mechanisms described above normally occur in combination accelerating or increasing the impact of low-cost traffic evolution at the airports that belong to the same airport system. Fig. illustrates the possible stages of the dynamic evolution of airport systems as a result of the identified mechanisms occurring in the airports. 


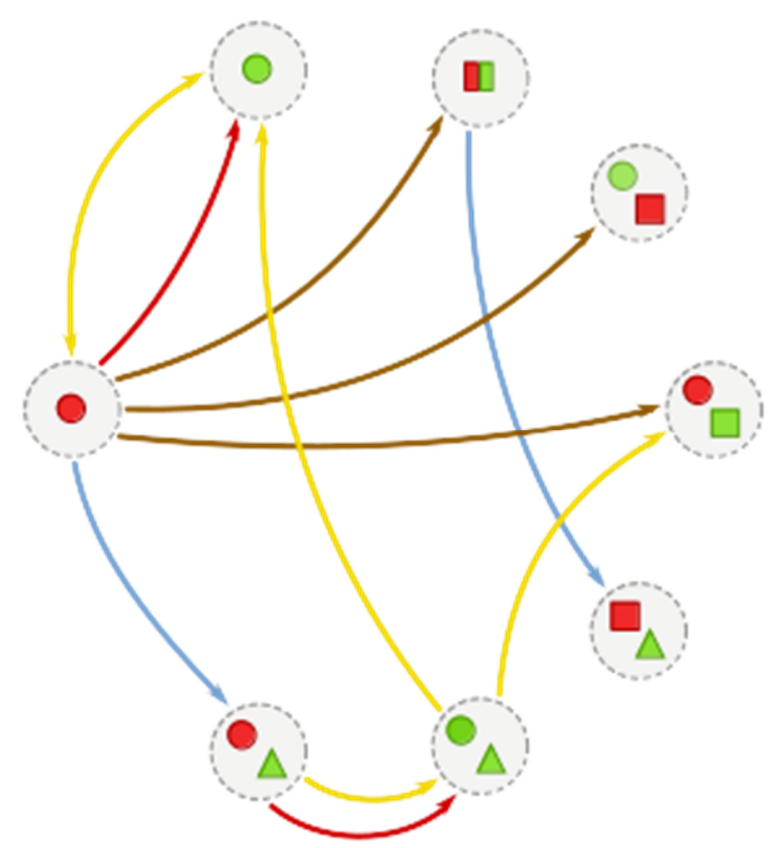

Components ofthe airport system:

Original primary airport with

low LCC market share

Original primary airport with

high LCC market share

New/emerged primary airport with

low LCC markt share

New/ennerged primary airport with

high LCC market share

New/emerged prinary airport

- designed for all types of traffc

$\triangle$ New/emerged secondary airport with

high LCC markst share

Mechanisms:

- Capacity expansion a. primary airport

- New/emerged prinary airport

- New/emerged secondary airport

- Market dynanics

Fig. 5. Conceptualisation of the dynamic evolution for airport systems in relation to low-cost traffic.

Considering an initial state in which the airport system is composed of an original primary airport where low-cost traffic is not relevant (not necessarily a single airport. London, for instance, had Heathrow and Gatwick before the development of Luton, Stansted, City and Southend), the system evolves into different stages as the mechanisms trigger different traffic patterns. The stages are defined by the airports included in the system and the level of low-cost traffic in each airport.

Once the airport system transitions to a new stage, market dynamics are the main mechanism through which the system can reach a different stage. Alternatively, any new state can be considered as an initial state for the future evolution of the system according to the development of the market conditions and the regulatory environment that is uncertain. Perhaps the most likely transition from any state with more than one airport is related to closing airports to concentrate all traffic segments in a single airport (as in Berlin, whenever the new airport opens). Likewise, the most likely transition from a state involving one airport is the expansion of the airport system by developing emergent airports possibly focused on a given type of traffic (not necessarily low-cost, as airline business models may evolve in different directions in the long-term).

\section{Conclusions and policy implications}

LCCs in Europe have significantly impacted both major and secondary airports. By analysing historical traffic and the key recent events that affected the evolution of 42 European airports, 38 of them part of Multi-Airport Systems, this paper proposed a conceptual model to explain the dynamic evolution of airport systems in relation to low-cost traffic. Four mechanisms normally trigger different stages of lowcost traffic development: i) Capacity expansion at primary airports; ii) New/emerged primary airports; iii) New/emerged secondary airports; and iv) Market dynamics. 
The first three mechanisms are related to the development of physical infrastructure that encouraged the growth of LCCs, even when not aimed directly at them. The fourth mechanism involves the occurrence of events that affect either the airlines that use the airports or the airports themselves (e.g. bankruptcies, mergers and acquisitions, change of strategy focus, emergence of start-up or spin-off airlines, creation or abandonment of bases or hubs, etc.).

More research is needed to conclude on the causality of the interactions between the mechanisms. Some cases suggest that infrastructure-related dynamics trigger market dynamics. In Barcelona or Alicante, for instance, the new passenger buildings provided sufficient capacity for LCCs to move and grow strongly in the primary airports. However, these two openings, particularly in Barcelona El Prat, occurred amid harsh economic times. Under such conditions, traditional carriers were already struggling to provide service, let alone to expand, and airports were eager to start repaying their investments. Common ownership of most Spanish commercial airports hinders this analysis in the sense that market dynamics could have been different should the management of every airport in the MAS be able to respond independently.

This paper contributes a dynamic perspective that is usually missing in existing analysis on the impact LCCs have had at European airports. Understanding the dynamics that impact the evolution of airport systems is paramount in forecasting uncertain future traffic levels in an industry with strong variability due to LCC entrance and withdrawal. Our findings highlight the need for a new paradigm in airport strategic development that incorporates the planning and design of infrastructure, along with the definition of a corresponding business strategy. Encompassing infrastructure and business plans, airport planners and managers can aim at ensuring long-term sustainability.

Moreover, understanding the dynamics that we identified and the interaction between them may prove valuable for policy making. As some European regions keep promoting the development of air transportation as a means to foster local economies, it is crucial to understand that infrastructure provision alone cannot guarantee a desired outcome. Moreover, infrastructure developments in one airport may greatly influence the evolution of traffic (and jobs, tourism and commercial opportunities) in other airports, even when airport competition is not explicitly considered. This points out to the importance of considering uncertainty in airport strategic planning, as infrastructure may become available under conditions that are radically different than those initially foreseen.

\section{Acknowledgements}

This work was financed by the ERDF European Regional Development Fund through the COMPETE Programme (operational programme for competitiveness) and by National Funds through FCT Fundação para a Ciência e a Tecnologia (Portuguese Foundation for Science and Technology) within the project Airdev/MIT-Pt/TS-AAS/0046/2008. Support for this research was also provided by FCT through the MIT Portugal Program under Grant SFRH/BD/51128/2010. The authors acknowledge the 
valuable contribution of the two reviewers and the journal editor, which greatly improved the final results.

\section{References}

Abda, M. B., Belobaba, P. P., \& Swelbar, W. S. (2012). Impacts of LCC growth on domestic traffic and fares at largest US airports. Journal of Air Transport Management, 18(1), 21-25. https://doi.org/10.1016/j.jairtraman.2011.07.001

AENA. (2014). Estadísticas - Aeropuertos Españoles y Navegación Aérea. Retrieved 1 August 2014, from http://www.aenaaeropuertos.es/csee/Satellite?pagename=Estadisticas/Home

Barbot, C. (2006). Low-cost airlines, secondary airports, and state aid: An economic assessment of the Ryanair-Charleroi Airport agreement. Journal of Air Transport Management, 12(4), 197-203. https://doi.org/10.1016/j.jairtraman.2006.04.001

Barret, S. D. (2004). How do the demands for airport services differ between full-service carriers and low-cost carriers? Journal of Air Transport Management, 10(1), 33-39. https://doi.org/10.1016/j.jairtraman.2003.10.006

Bonnefoy, P. (2008). Scalability of the air transportation system and development of multiairport systems: A worldwide perspective (Doctor Of Philosophy in Engineering Systems). Massachusetts Institute of Technology, Cambridge. Retrieved from http://hdl.handle.net/1721.1/46800

CAA. (2014). UK Airport Statistics | Aviation Intelligence | About the CAA. Retrieved 29 August 2014, from

http://www.caa.co.uk/default.aspx?catid=80\&pagetype=88\&pageid=3\&sglid=3

Copenhagen Economics. (2012). Airport competition in Europe. ACI Europe.

de Neufville, R. (1995a). Management of multi-airport systems: A development strategy.

Journal of Air Transport Management, 2(2), 99-110. https://doi.org/10.1016/09696997(95)00035-6

de Neufville, R. (1995b). Policy Guidelines for the Option of a Development of a Multi-Airport System, the basis of a Dynamic Strategic Plan to provide the capability for flexible response to future challenges. Report Prepared for Amsterdam Airport Schiphol, Netherlands. Retrieved from http://ardent.mit.edu/airports/ASP_papers/multi- 
airport\%20systems\%20policy\%20guidelines.PDF

de Neufville, R. (2008). Low-Cost Airports for Low-Cost Airlines: Flexible Design to Manage the Risks. Transportation Planning and Technology, 31(1), 35-68. https://doi.org/10.1080/03081060701835688

de Neufville, R., \& Odoni, A. R. (2003). Airport systems: planning, design, and management. New York: McGraw-Hill.

Dobruszkes, F. (2006). An analysis of European low-cost airlines and their networks. Journal of Transport Geography, 14(4), 249-264. https://doi.org/10.1016/j.jtrangeo.2005.08.005

Dobruszkes, F. (2009). New Europe, new low-cost air services. Journal of Transport Geography, 17(6), 423-432. https://doi.org/10.1016/j.jtrangeo.2009.05.005

Dobruszkes, F. (2013). The geography of European low-cost airline networks: a contemporary analysis. Journal of Transport Geography, 28(0), 75-88. https://doi.org/10.1016/j.jtrangeo.2012.10.012

Dobruszkes, F., Givoni, M., \& Vowles, T. (2017). Hello major airports, goodbye regional airports? Recent changes in European and US low-cost airline airport choice. Journal of Air Transport Management, 59, 50-62. https://doi.org/10.1016/j.jairtraman.2016.11.005

Dunn, J. C. (1974). Well-separated clustersand optimal fuzzy partitions. Journal of Cybernetics, 4(1), 95-104.

European Parliament. (2007). The consequences of the growing European low-cost airline sector. Directorate-General for Internal Policies of the Union. Retrieved from http://www.europarl.europa.eu/activities/expert/eStudies.do?language=EN

Forgy, E. (1965). Cluster analysis of multivariate data: efficiency versus interpretability of classifications. Biometrics, 21, 768-769.

Francis, G., Fidato, A., \& Humphreys, I. (2003). Airport-airline interaction: the impact of lowcost carriers on two European airports. Journal of Air Transport Management, 9(4), 267-273. https://doi.org/10.1016/S0969-6997(03)00004-8

Francis, G., Humphreys, I., \& Ison, S. (2004). Airports' perspectives on the growth of low-cost airlines and the remodeling of the airport-airline relationship. Tourism Management, 
25(4), 507-514. https://doi.org/10.1016/S0261-5177(03)00121-3

Franke, M. (2004). Competition between network carriers and low-cost carriers-retreat battle or breakthrough to a new level of efficiency? Journal of Air Transport Management, 10(1), 15-21. https://doi.org/10.1016/j.jairtraman.2003.10.008

Gillen, D., \& Lall, A. (2004). Competitive advantage of low-cost carriers: some implications for airports. Journal of Air Transport Management, 10(1), 41-50. https://doi.org/10.1016/j.jairtraman.2003.10.009

Graham, A. (2013). Understanding the low cost carrier and airport relationship: A critical analysis of the salient issues. Tourism Management, 36, 66-76. https://doi.org/10.1016/j.tourman.2012.11.011

Graham, B., \& Shaw, J. (2008). Low-cost airlines in Europe: Reconciling liberalization and sustainability. Geoforum, 39(3), 1439-1451. https://doi.org/10.1016/j.geoforum.2007.12.006

IATA. (n.d.). Innovata the SRS Provider. Retrieved 31 July 2014, from http://www.iata.org/publications/srs/Pages/innovata.aspx

Jimenez, E. (2015). Airport strategic planning in the context of low-cost carriers ascendency: insights from the European experience (PhD Thesis). Universidade do Porto, Porto, Portugal. Retrieved from http://repositorio-aberto.up.pt/handle/10216/78345

Jimenez, E., Claro, J., \& Pinho de Sousa, J. (2013). The airport business in a competitive environment. European Journal of Transport and Infrastructure Research, 13(4), 315335.

Lloyd, S. (1982). Least squares quantization in PCM. IEEE Transactions on Information Theory, 28(2), 129-137. https://doi.org/10.1109/TIT.1982.1056489

Malighetti, P., Paleari, S., \& Redondi, R. (2008). Connectivity of the European airport network: 'Self-help hubbing' and business implications. Journal of Air Transport Management, 14(2), 53-65. https://doi.org/10.1016/j.jairtraman.2007.10.003

Malighetti, P., Paleari, S., \& Redondi, R. (2009). Pricing strategies of low-cost airlines: The Ryanair case study. Journal of Air Transport Management, 15(4), 195-203. https://doi.org/10.1016/j.jairtraman.2008.09.017

Malighetti, P., Redondi, R., Martini, G., \& Paleari, S. (2007). An empirical investigation on the 
efficiency, capacity and ownership of Italian airports. Rivista Di Politica Economica. Retrieved from

http://citeseerx.ist.psu.edu/viewdoc/download?doi=10.1.1.586.1925\&rep=rep1\&type $=\mathrm{pdf}$

Martini, G., Manello, A., \& Scotti, D. (2013). The influence of fleet mix, ownership and LCCs on airports' technical/environmental efficiency. Transportation Research Part E: Logistics and Transportation Review, 50, 37-52. https://doi.org/10.1016/j.tre.2012.10.005

Pels, E., Njegovan, N., \& Behrens, C. (2009). Low-cost airlines and airport competition. Transportation Research Part E: Logistics and Transportation Review, 45(2), 335-344. https://doi.org/10.1016/j.tre.2008.09.005

Rousseeuw, P. J. (1987). Silhouettes: a graphical aid to the interpretation and validation of cluster analysis. Journal of Computational and Applied Mathematics, 20, 53-65.

Zhang, A., Hanaoka, S., Inamura, H., \& Ishikura, T. (2008). Low-cost carriers in Asia: Deregulation, regional liberalization and secondary airports. Research in Transportation Economics, 24(1), 36-50. https://doi.org/10.1016/j.retrec.2009.01.001 


\section{Annex A - Summary of the multiple-case study: Major events at sampled airports over the period}

of study (2004 - 2013)

\begin{tabular}{|c|c|c|c|}
\hline MAS & Airport & Infrastructure dynamics & Market dynamics \\
\hline \multirow{10}{*}{ Alicante } & \multirow{7}{*}{ ALC } & \multirow{7}{*}{$\begin{array}{l}2007 \text { - New passenger building T2 opened } \\
2011 \text { - New passenger building TN opened (declared } \\
\text { capacity } 20 \text { million annual passengers) }\end{array}$} & 2002 - easyJet acquired Go (British Airways LCC spin-off) \\
\hline & & & and became major airline at ALC \\
\hline & & & 2007 - Ryanair started operations and opened a base \\
\hline & & & $\begin{array}{l}2009 \text { - Decline in total passengers due to economic } \\
\text { downturn }\end{array}$ \\
\hline & & & $\begin{array}{l}2011 \text { - } 2012 \text { - Legal dispute between Ryanair and AENA } \\
\text { over the use of jet bridges (-1 million passengers for } \\
\text { Ryanair in } 2012 \text { vs. 2011) }\end{array}$ \\
\hline & & & $\begin{array}{l}2012 \text { - } 2013 \text { - Dispute settled (+0,3 million passengers for } \\
\text { Ryanair in } 2013 \text { vs. } 2012 \text { ) }\end{array}$ \\
\hline & & & $\begin{array}{l}2013 \text { - Iberia abandons ALC. Replaces services with Iberia } \\
\text { Express then with Air Nostrum }\end{array}$ \\
\hline & \multirow{3}{*}{ MJV } & 2004 - Passenger building expansion & 2007 - Ryanair concentrated growth at ALC \\
\hline & & 2006 - Passenger building expansion & 2011 - Jet2.com concentrated growth at ALC \\
\hline & & $\begin{array}{l}2011 \text { - New runway opened exclusively for military } \\
\text { operations }\end{array}$ & \\
\hline \multirow{8}{*}{ Amsterdam } & \multirow[b]{2}{*}{ AMS } & $\begin{array}{l}2003 \text { - New runway } 18 \mathrm{R} / 36 \mathrm{~L} \text { (Polderbaan) opened (mostly } \\
\text { for noise control considerations) }\end{array}$ & $\begin{array}{l}2005 \text { - Transavia (Holland) converts from charter airline to } \\
\text { LCC }\end{array}$ \\
\hline & & $\begin{array}{l}2005 \text { - “Low-cost pier" (H/M) opened (Transavia does not } \\
\text { use it) }\end{array}$ & \\
\hline & \multirow[b]{2}{*}{ RTM } & $\begin{array}{l}\text { Expansions opportunities are limited due to lack of space } \\
\text { available in airport location }\end{array}$ & $\begin{array}{l}2005 \text { - Transavia (Holland) converts from charter airline to } \\
\text { LCC }\end{array}$ \\
\hline & & & $\begin{array}{l}2004 \text { - } 2013 \text { Business service to LHR and LCY changed } \\
\text { operator: from KLM to Air France to British Airways } \\
\text { and City jet }\end{array}$ \\
\hline & \multirow{4}{*}{ EIN } & 2003 - New passenger building opened (declared capacity: & 2002 - Ryanair started operations \\
\hline & & 1,5 million annual passengers) & 2005 - Transavia (Holland) converts from charter airline to \\
\hline & & 2013 - Passenger building expansion opened (declared & LCC \\
\hline & & capacity: 5 million annual passengers) & 2013 - Ryanair opens base \\
\hline \multirow{19}{*}{ Barcelona } & \multirow{12}{*}{$\mathrm{BCN}$} & 2003 - Expansion of passenger buildings TA and TB & 2004 - Vueling starts as independent LCC \\
\hline & & 2004 - New runway opened & 2006 - Iberia transfer all flights but "airbridge" MAD - BCN \\
\hline & & 2007 - New building to connect terminals TA and TB & to LCC spin-off Clickair \\
\hline & & opened & $2007-B C N-M A D$ was the busiest route in the world (971 \\
\hline & & 2008 - Expansion of passenger building TC opened & flights per week in both directions according to OAG) \\
\hline & & $\begin{array}{l}2009 \text { - New passenger building T1 opened (declared } \\
\text { capacity: } 55 \text { million annual passengers). Buildings TA, }\end{array}$ & $\begin{array}{l}2007 \text { - Air Europa reduced services to focus on hub } \\
\text { development at MAD }\end{array}$ \\
\hline & & $\begin{array}{l}\text { TB and TC rebranded T2. T2A closed. Vueling moved } \\
\text { operations to T1, all other LCCs use T2. }\end{array}$ & $\begin{array}{l}2008 \text { - AVE High-Speed Rail line Barcelona - Madrid } \\
\text { opened in February }\end{array}$ \\
\hline & & & 2008 - Economic recession affected passenger numbers \\
\hline & & & $\begin{array}{l}2009 \text { - Merger between Vueling and Clickair (Iberia } \\
\text { acquires stake at Vueling) }\end{array}$ \\
\hline & & & 2010 - Ryanair opens base \\
\hline & & & 2012 - Spanair (Catalonia's FSC) goes bankrupt \\
\hline & & & $\begin{array}{l}2013 \text { - IAG (British Airways + Iberia) takes over Vueling } \\
\text { entirely }\end{array}$ \\
\hline & \multirow{3}{*}{ GRO } & (No major expansions during the analysis period) & $\begin{array}{l}2002 \text { - Ryanair enters the Spanish market with services at } \\
\text { GRO }\end{array}$ \\
\hline & & & 2004 - Ryanair opens base \\
\hline & & & 2011 - Ryanair downsizes base \\
\hline & \multirow{4}{*}{ REU } & 2005 - New arrivals building & 2008 - Ryanair opens base \\
\hline & & $\begin{array}{l}2008 \text { - New "check-in building" connecting arrivals and } \\
\text { departures buildings }\end{array}$ & 2011 - Ryanair closes base \\
\hline & & 2009 - Apron expansion for new aircraft stands & \\
\hline & & 2010 - New boarding area & \\
\hline \multirow{5}{*}{ Brussels } & & 2007 - Plan to develop "low-cost pier" announced & 2001 - Sabena went bankrupt ((became SN Brussels) \\
\hline & BRU & 2011 - Plan to develop "low-cost pier" abandonned & $\begin{array}{l}2006 \text { - SN Brussels and LCC Virgin Express merge to form } \\
\text { Brussels Airlines }\end{array}$ \\
\hline & \multirow{3}{*}{ CRL } & \multirow{3}{*}{$\begin{array}{l}2008 \text { - New passenger building and apron extension } \\
\text { opened (declared capacity: } 5 \text { million annual } \\
\text { passengers) }\end{array}$} & $\begin{array}{l}1997 \text { - Charleroi becomes one of the first four Ryanair } \\
\text { destinations in continental Europe }\end{array}$ \\
\hline & & & $\begin{array}{l}2001 \text { - Ryanair opens its firs base in continental Europe } \\
\text { following an agreement with the Walloon } \\
\text { government }\end{array}$ \\
\hline & & & 2004 - WizzAir start services \\
\hline
\end{tabular}




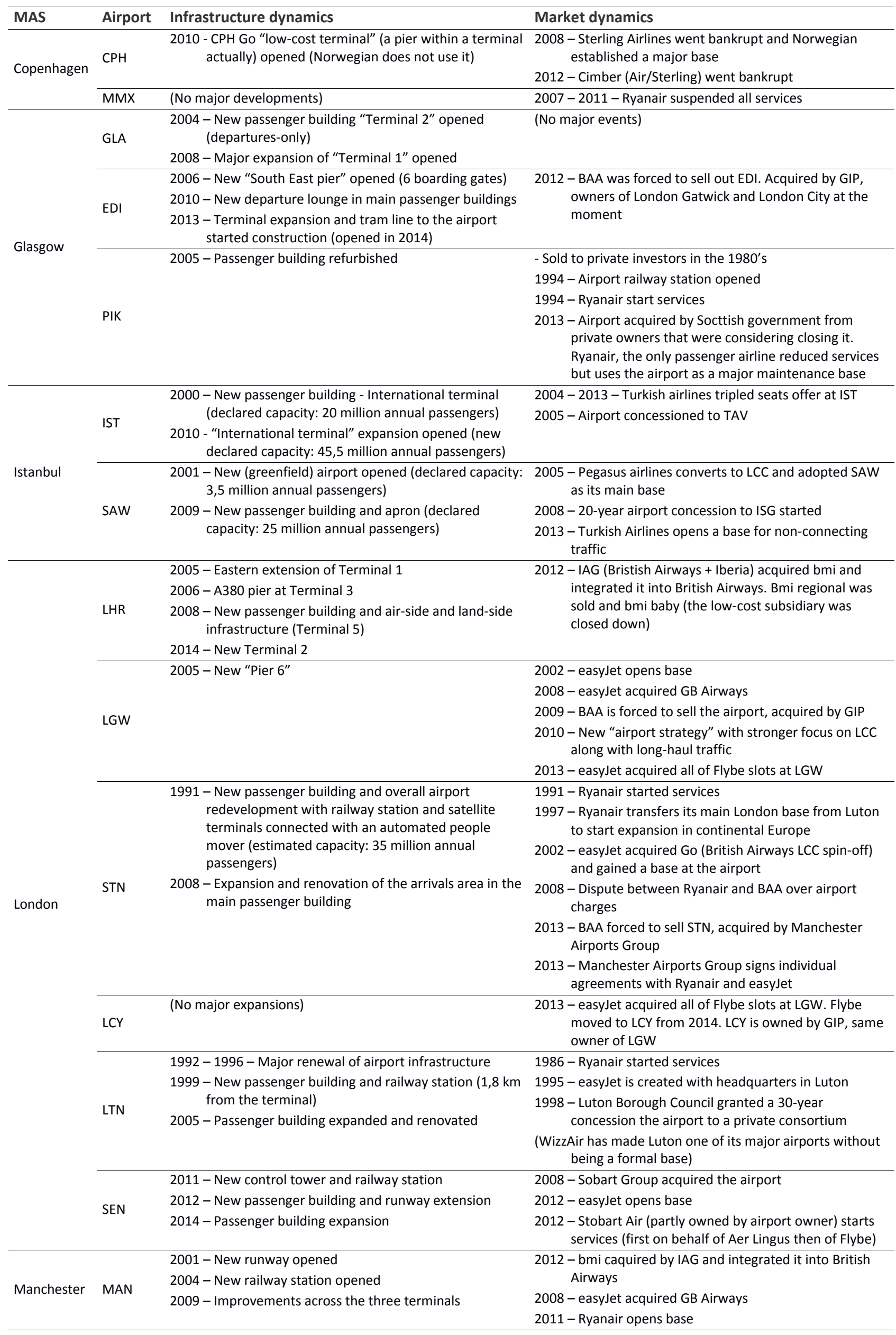




\begin{tabular}{|c|c|c|c|}
\hline MAS & Airport & Infrastructure dynamics & Market dynamics \\
\hline & \multirow{2}{*}{ LPL } & \multirow{2}{*}{2002 - New passenger building opened } & 1997 - easyJet opens its second base after Luton \\
\hline & & & 2004 - Ryanair opens base \\
\hline & \multirow{3}{*}{ LBA } & \multirow[t]{3}{*}{ (No major developments) } & $\begin{array}{l}2003 \text { - Jet2.com is created as a spin-off from freight and } \\
\text { charter carrier Channel Express }\end{array}$ \\
\hline & & & 2007 - Airport privatised \\
\hline & & & 2010 - Ryanair opens base \\
\hline \multirow{13}{*}{ Milan } & \multirow{5}{*}{ MXP } & \multirow{5}{*}{$\begin{array}{l}1998 \text { - New passenger building "Terminal 1" opened, part } \\
\text { of “Malpensa 2000" plan for a hub in the region } \\
2013 \text { - New satellite terminal for Terminal } 1\end{array}$} & 1998 - Alitalia established main hub at MXP \\
\hline & & & 2005 - easyJet starts services \\
\hline & & & $\begin{array}{l}2006 \text { - "Terminal 2" dedicated as "low-cost terminal" and } \\
\text { easyJet opens base. The airline is the sole user of } \\
\text { "Terminal 2" and the largest airline at MXP since } \\
\text { Alitalia's dehubbing }\end{array}$ \\
\hline & & & 2008 - Alitalia moved its main hub back to Rome Fiumicino \\
\hline & & & $\begin{array}{l}2009 \text { - } 2011 \text { Lufthansa created "Lufthansa Italy" with a hub } \\
\text { at MXP. The subsidiary transferred back operations } \\
\text { to the parent airline in October } 2011\end{array}$ \\
\hline & & (No major expansions) & The airport was due to reduce its services (all but a shuttle \\
\hline & LIN & & $\begin{array}{l}\text { service to Rome) after MXP renovation in } 1998 . \text { This } \\
\text { downscaling was never realised. }\end{array}$ \\
\hline & & 2005 - Parking lot expansion and aviation equipment & 2002 - Ryanair started services \\
\hline & & improved & 2003 - Ryanair opens base (by 2013 it was the largest base \\
\hline & & 2007 - Refurbishment of check-in area and baggage & in continental Europe) \\
\hline & BGY & handling system & The airport holds a long-term agreement with Ryanair \\
\hline & & 2009 - Extension and renewal of departures area & (until 2022) \\
\hline & & $\begin{array}{l}2010 \text { - Passenger building expansion increasing boarding } \\
\text { gates and commercial space air-side }\end{array}$ & \\
\hline & & $\begin{array}{l}1998 \text { - New (greenfield) airport opened (old Oslo Airport } \\
\text { Fornebu closed and was dismantled) }\end{array}$ & Largest base for Norwegian \\
\hline & OSL & $\begin{array}{l}2012 \text { - "Pier South" opened (intended as a temporary } \\
\text { extension whilst work progress on a major expansion) }\end{array}$ & \\
\hline Oslo & & $\begin{array}{l}2007 \text { - Airport redevelopment (from former exclusive } \\
\text { military use) opened (declared capacity: } 2 \text { million }\end{array}$ & $\begin{array}{l}2008 \text { - Norwegian opens base, closed in 2012. Services } \\
\text { moved to TRF }\end{array}$ \\
\hline & RYG & annual passengers & 2010 - Ryanair opens base \\
\hline & & & $\begin{array}{l}2016 \text { - Airport closed to civilian use after Ryanair closed } \\
\text { the based and moved back to TRF }\end{array}$ \\
\hline & TRF & 2003 - New international terminal opened & $\begin{array}{l}1997 \text { - Ryanair started services. Moved partly to RYG in } \\
2010\end{array}$ \\
\hline & & $\begin{array}{l}2003 \text { - Passenger building Terminal 2E opened (part of its } \\
\text { boarding dock collapsed and reopened in 20008) }\end{array}$ & $\begin{array}{c}\text { Terminal } 3 \text { is referred as "low-cost terminal". It is used } \\
\text { mainly by charters and small LCCs. easyJet, the }\end{array}$ \\
\hline & & $\begin{array}{l}2007 \text { - Automated People Mover (CDGVAL) opened } \\
\text { (connects main passenger buildings except } 2 \mathrm{G} \text { ) }\end{array}$ & $\begin{array}{l}\text { largest LCC at CDG (sixth largest base for the carrier) } \\
\text { uses other terminal. }\end{array}$ \\
\hline & & 2007 - Satellite 3 of Terminal 2E (Hall L) opened & \\
\hline & CDG & $\begin{array}{l}2008 \text { - Terminal } 2 G \text { dedicated to regional flights in small } \\
\text { aircraft opened }\end{array}$ & \\
\hline & & 2009 - Terminal 1 renovation & \\
\hline & & $\begin{array}{l}2012 \text { - Connecting building between Terminal 2A and } \\
\text { Terminal } 2 \mathrm{C} \text { opened }\end{array}$ & \\
\hline Paris & & 2012 - Satellite 4 of Terminal 2E (Hall M) opened & \\
\hline & & 2006 - Renovation of Hall 2 in Terminal Ouest (West) & 2007 - Transavia France (Air France LCC spin-off and sister \\
\hline & $\mathrm{ORY}$ & $2007-2008$ - Renovation of Terminal Sud (South) & company of Transavia Holland) starts operations \\
\hline & ORY & $\begin{array}{l}2013 \text { - RATP tram line T7 opens connecting the airport to } \\
\text { metro line } 7 \text { and suburbs in South Paris }\end{array}$ & based at ORY \\
\hline & BVA & 2010 - Passenger building “Terminal 2" opened & $\begin{array}{l}1997 \text { - Ryanair start services to continental Europe after } \\
\text { market liberalisation, BVA was one of the initial four } \\
\text { destinations }\end{array}$ \\
\hline & & & (The airport is not a base for any airline) \\
\hline & YCP & 2000 - Airport redeveloped to focus on cargo traffic & (No major events) \\
\hline & XCR & 2004 - New passenger building intended for LCCs opened & \\
\hline & & (FCO opened in the 1960 's to replace $\mathrm{CIA}$, which lacked & 2008 - easyJet moved all its flights from CIA to FCO \\
\hline & & expansion opportunities. $\mathrm{CIA}$ remained open for & 2008 - Vueling starts services \\
\hline & FCO & charters and general aviation, and later LCCs) & 2008 - Air One and Alitalia merge \\
\hline & & 2008 - "Terminal 5" opened (only departures to US and & 2012 - Vueling opens base \\
\hline Rome & & Israel in some airlines) & 2013 - Ryanair opens base \\
\hline & & 2007 - ENAC (Italian civil aviation authority) capped the & 2008 - easyJet moved all its flights from CIA to FCO \\
\hline & $\mathrm{ClA}$ & $\begin{array}{l}\text { number of flights per day allowed at CIA to control } \\
\text { noise (100 movements/day) }\end{array}$ & $\begin{array}{l}\text { Ryanair is the largest user at CIA and WizzAir is the only } \\
\text { other airline with scheduled services }\end{array}$ \\
\hline
\end{tabular}




\begin{tabular}{|c|c|c|c|}
\hline MAS & Airport & Infrastructure dynamics & Market dynamics \\
\hline \multirow{5}{*}{ Malaga } & \multirow{5}{*}{ AGP } & \multirow{2}{*}{$\begin{array}{l}2010 \text { - New passenger building "Terminal 3". "Terminal 2" } \\
\text { was merged with the new building and "Terminal 1" } \\
\text { closed }\end{array}$} & 2007 - Clickair (Iberia's LCC spin-off) opens base \\
\hline & & & $\begin{array}{l}2009 \text { - Merger between Vueling and Clickair (Iberia } \\
\text { acquires stake at Vueling), Vueling inherits base }\end{array}$ \\
\hline & & \multirow{3}{*}{$\begin{array}{l}2010 \text { - New railway station opened } \\
2012 \text { - New runway opened, along with apron and } \\
\text { taxiways }\end{array}$} & 2010 - Ryanair opens base \\
\hline & & & 2012 - Spanair (Catalonia's FSC) goes bankrupt \\
\hline & & & 2012 - Iberia ceased services at AGP \\
\hline \multirow{5}{*}{ Dublin } & \multirow{5}{*}{ DUB } & \multirow{5}{*}{$\begin{array}{l}2007 \text { - New “Pier D” (no jet bridges) for Terminal } 1 \text { (used } \\
\text { for all Ryanair flights) } \\
2010 \text { - New passenger building (Terminal 2). Ryanair, main } \\
\text { user at DUB, opposed this development }\end{array}$} & $2009-2010$ - Irish financial recession \\
\hline & & & (Ryanair headquarters are located in DUB, which is a \\
\hline & & & $\begin{array}{l}\text { destination for the airline since its inception in 1986, } \\
\text { before turning LCC in } 1990 \text {. Between } 2004 \text { and } 2008\end{array}$ \\
\hline & & & Ryanair became the largest carrier. By 2012 \\
\hline & & & $\begin{array}{l}\text { AerLingus was again the largest carrier after Ryanair } \\
\text { reduced service in opposition to the new Terminal 2) }\end{array}$ \\
\hline \multirow{8}{*}{ Madrid } & \multirow{8}{*}{ MAD } & 1998 - 2006 “Plan Barajas deployment” & 2006 - Ryanair opens base \\
\hline & & \multirow{7}{*}{$\begin{array}{l}2006 \text { - New passenger buildings Terminal } 4 \text { and satellite } \\
\text { Terminal } 4 \text { S, and associated aprons, taxiways and } \\
\text { traffic control (declared capacity of the expansion: } \\
35 \text { million annual passengers; of the airport: } 70 \\
\text { million annual passengers). All LCCs (except Vueling } \\
\text { and Iberia Express) operate in Terminal 1-2-3 }\end{array}$} & 2007 - easyJet opens base \\
\hline & & & $\begin{array}{l}2007 \text { - BCN - MAD was the busiest route in the world (971 } \\
\text { flights per week in both directions according to OAG) }\end{array}$ \\
\hline & & & 2007 - Air Europa focuses on hub development at MAD \\
\hline & & & $\begin{array}{l}2008 \text { - AVE High-Speed Rail line Barcelona - Madrid } \\
\text { opened in February }\end{array}$ \\
\hline & & & $\begin{array}{l}2012 \text { - Ryanair downsize operations following airport fees } \\
\text { increase }\end{array}$ \\
\hline & & & 2012 - Iberia creates LCC spin-off Iberia Express \\
\hline & & & 2013 - easyjet closed base \\
\hline \multirow{5}{*}{ Palma } & \multirow{5}{*}{ PMI } & $\begin{array}{l}2003 \text { - New passenger building "Module B" for inter-island } \\
\text { traffic only }\end{array}$ & $\begin{array}{l}\text { (Air Europa headquarters are located in PMI, which is the } \\
\text { second largest airport for the airline. }\end{array}$ \\
\hline & & $\begin{array}{l}\text { (Passenger building "Module } A \text { " is used only during } \\
\text { summer season) }\end{array}$ & $\begin{array}{l}\text { It is also the third largest airport in Air Berlin's network. Air } \\
\text { Berlin changed business model from FSC to LCC in }\end{array}$ \\
\hline & & \multirow{3}{*}{$\begin{array}{l}2011 \text { - Expansion and refurbishment of "Module C" } \\
\text { concourse }\end{array}$} & early 2000 's) \\
\hline & & & 2007 - Ryanair started services \\
\hline & & & 2012 - Ryanair opens base \\
\hline
\end{tabular}


2017-07-07

\section{Dynamic evolution of European airport systems in the context of low-cost carriers growth}

Jimenez Perez, Edgar

Elsevier

Jimenez E, Claro J, Pinho de Sousa J, de Neufville R. Dynamic evolution of European airport systems in the context of low-cost carriers growth. Journal of Air Transport Management, Volume 64, Part A, September 2017, pp. 68-76

https://doi.org/10.1016/j.jairtraman.2017.06.027

Downloaded from Cranfield Library Services E-Repository 